\title{
International Journal for Educational and Vocational Studies
}

\section{Differences in the delivery of the corner in a baby who was bathed in warm water with a baby whipped in a wet tool at batara siang hospital of Pangkep District}

\author{
Herman \\ STIKES Yapika Makassar, Makassar, Indonesia \\ hermanmm68@gmail.com \\ *Corresponding Author: hermanmm68@gmail.com | Phone Number: +628565976 7920
}

\section{ARTICLE INFO}

Received: 20-05-2021

Received in revised: 13-06-2021

Accepted: 28-07-2021

Available online: $30-8-2021$

\section{KEYWORDS}

Umbilical cord; Detachment;

Bathed; In a wet wipe;

\begin{abstract}
A B S T R A C T
WHO (2000), recommends umbilical cord care based on aseptic and dry principles and no longer recommended to use alcohol but with open care. The umbilical cord should also not be tightly closed with anything, because it will make it moist. In addition to slowing the release of the umbilical cord, it also poses a risk of infection. Even if you have to close. according to Taylor (2003, dalam Nopriyarti, 2013) cover or tie loosely at the top of the umbilical cord with sterile gauze. The research used quasiexperimental research. The design of this study used the Experimental Design- Equivalent Time Sample method, which is a quasi-experimental design by treating the experimental group (X1), namely taking a warm bath and the control group (X0), which was wiped with a wet towel, alternately with random determination (Suharsaputra, 2012). The mandatory output in this research is publishing international journals, while the additional output is publishing national journals it can be seen that the average length of umbilical cord detachment of infants who were bathed in warm water (experimental group) was 110.8 hours, while the average length of time to release the umbilical cord of infants who were wiped with a wet towel (control group) was 76.9 hours or 6.6 days. The average difference between the two groups is 24,72 hours. The results of the statistical test obtained a P-value $(<0.001)$, meaning that at alpha $5 \%$ there was a significant difference in the average length of umbilical cord detachment between babies who were wiped with a wet towel, which was 2.01 days and babies who were bathed in warm water, which was 4,01 day. So that the treatment of babies who are wiped with a wet towel is more effective and the umbilical cord is removed faster than the care of babies who are bathed in warm water. There was a significant difference between the In umbilical cord care, there was a significant difference in the average length of umbilical cord detachment between babies who were wiped with a wet towel and babies who were bathed in warm water.
\end{abstract}

\section{INTRODUCTION}

Care for newborns that is often taught by health workers to mothers before going home from the hospital or maternity home, one of them is how to treat the umbilical cord. In the weeks first that should be done is to clean the rope center of the base until the end. Newborn care requires prudence, care and thoroughness of its own. It is not another intended to reduce pain or a state that is worse due care interventions (Rakhmawati, 2007). Error intervention treatment allows the baby will respond are not desirable, for example at the moment do treatment ropes centers do not do it regularly and do not maintain the cleanliness of the area around the rope center will result in the rope center becomes wet and long dry. Response else that might be posed is the occurrence of infection rope center which - resulted in the rope center over long off (Rakhmawati,2007). The purpose of umbilical cord care is to prevent the occurrence of infectious diseases such as neonatal tetanus in newborns. Neonatorum tetanus is tetanus in newborns with typical clinical signs, after the first 2 days the baby is alive, cries and suckles normally, on the third day or so. There is more stiffness throughout the body which is characterized by difficulty opening the mouth and sucking, followed by convulsions (WHO, 1989 in Zakariah, 2014). The disease is caused by the entry of the spores of germs tetanus into the body through the ropes center, both of the tool sterile, use of drugs, powder or daun- herbs are sprinkled into the ropes center so it can lead to infection (MOH RI in Supriyanik, 2011). 
Indicators that affect the release of the rope center is treatment ropes center to keep that rope center stays dry and clean (Gultom, 2004 in Zuniyati et al, 2009). According Choirunisa (2009 in Musariah 2011) bathing the baby is a way to clean the body of the baby with the water by way of watering, immersing themselves in the water based on the sequences that correspond. Paisal (2007, in Supriyanik, 2011) said that before the umbilical cord off, the baby should not be bathed by being immersed in water. Quite wiped it with $\mathrm{m}$ water hangat.Alasannya to keep the rope center remains kering.Jika rope center soggy possibility occurred infection is great for wet umbilical cord is a place that is good for the breeding of germs and bacteria including spore bacteria tetanus. The point is to let the rope center hit by air then the rope center will quickly dry out and loose. Benefits of treatment rope center are good and true that cord center akanlepas about 5-7 days after the baby is born without no complications (Saleha, 2009).

The Infant Mortality Rate (IMR) in Indonesia is still relatively high, when compared to other countries in the ASEAN region. Based on the 2010 Human Development Report, the IMR in Indonesia reached 31 per 1,000 births. Newborn mortality of $79 \%$ occurs in the first week of birth, especially during childbirth. The main causes of newborn mortality are prematurity and low birth weight (29\%), asphyxia (breathing disorders) new baby is born $(27 \%)$, tetanus neonatorum (10\%) and breast feeding problems (10\%) (Bejo, 2010). Infection as a cause of neonatal death is still common. This infection includes neonatal tetanus. Around 12 countries with high neonatal tetanus cases, including Indonesia. The survey results show the number of deaths due to tetanus neonatorum highest in the infectious disease (9, 5 \%) (Ellen, 2003, in Dwisuda 2009) .

WHO (2000), recommends umbilical cord care based on aseptic and dry principles and it is no longer recommended to use alcohol but with special care. The umbilical cord should also not be tightly closed with anything, because it will make it damp. In addition to slowing the release of the umbilical cord, it also poses a risk infeksi. Even if it had to be closed, according to Taylor (2003, in Nopriyarti, 2013) or tie with a loose lid on the part of the top rope center with gauze sterile. The results of the study Masninon (2013) which entitled the difference effectiveness of treatment ropes center with or without the use of alcohol to the old release cord center at the baby just born in RSIA Kasih Ibu and RSIA Harapan Bunda Pangkalan Kerinci, obtained the result that there is a difference between treatments rope center using alcohol care umbilical cord without the use of use of alcohol on the long release cord center at the baby just born with a value of $t=4.583$ with $p$ value of 0.000 ( $p<0.05$ ). Research is using the technique to bathe the baby by the way is washed into the water warm.
Pangkep Regency there are two Houses Hospital namely Home Hospital General Regional (Hospital) Primary Pangekp district and hospital district Common area Lunch Pangkep Batara. Batara Siang Hospital in Pangkep Regency is one of the government hospitals in Pangkep Regency that serves maternal and child patients . with the total number of births per month is 20 people/month compared with hospitals that others.

Based on the results of interviews with midwives implementing and midwife aides said that the average price lepasny a tai center of babies are in care in there could reach 7 - 8 days as they have a habit of bathing infants who were treated with the system wash disposable basin so talipusatnya submerged when dimandiakan. In the treatment of rope center they 've been taking care of the system dry sterl without describing the akohol or betadine at the center baby. Seeing the length of time the baby's umbilical cord was removed at the Batara Siang Regional General Hospital, Pangkep Regency. For it is necessary to do research on "Differences Old release of Tali Center On Babies are washed to In Water Warm by Baby Wiped with Wet Towel at Batara Siang Regional General Hospital, Pangkep Regency.

\section{Problem Formulation}

The formulation of the problem in the study of this is whether there is "difference Lama release of Tali Center On Babies are washed to In Hot Water With Baby wiped Towels at the District General Hospital Lunch god Pangkep. 2020 year?.

\section{Research Objectives}

a. To determine the distribution of the long release cord center in infants who bathed in warm water at the District General Hospital Lunch god Pangkep. 2020 year?.

b. To determine the distribution of long release cord center in infants who wiped a wet towel on the Regional General Hospital Siang district god Pangkep 2020.

c. To know the difference long release cord center in infants who bathed in warm water with a baby who wiped a towel soaked in the District General Hospital god Pangkep during 2020.

\section{RESEARCH METHODS}

\section{Research Type and Design}

The type of research used in this study is a quasiexperimental research (quasi-experimental). The design of this study uses the Experimental Design-Equivalent Time Sample method. The populations of this study were all maternity mothers who came to the Batara Siang District General Hospital, Pangkep Regency. In general, the minimum number of samples for experimental research is 
25 in the experimental group and 25 in the group. Sampling uses the Accidental Sampling technique. To get the difference between the two variables in the research, the scale used is the ratio scale. Statistical tests are carried out by computerization, using the Independent Sample $\mathrm{T}$ test formula.

\section{RESEARCH RESULT}

Table 4.4 Differences in the length of the release of the umbilical cord in babies who are bathed in warm water with babies who are wiped with wet towels at Husada Bunda Hospital in 2018

From table 4.4. The results of the statistical test obtained a P-value $(<0.001)$, meaning that at $5 \%$ alpha there was a significant difference in the average length of umbilical cord detachment between babies who were wiped with a wet towel, which was 76.9 hours or 6.6 days, and babies who were bathed in water. warm is 110.8 hours or 4.97 days. So that the treatment of babies who are wiped with a wet towel is more effective and the umbilical cord is removed faster than the care of babies who are bathed in warm water.

\section{DISCUSSION}

The difference in the length of the release of the umbilical cord for a baby who is bathed in warm water with a baby who is wiped with a wet towel at the Batara Noon General Hospital, Pangkep Regency in 2020

Based on the results of the study, it can be seen that there is a difference in the mean (mean) length of umbilical cord detachment in the group of babies who are bathed in warm water with the babies being wiped with a wet cloth. The mean value of baby care by bathing in warm water is 110.8 and baby care by wiping wet towels of 76.9 with a $P$ value of $0.001(p<0.05)$. It can be concluded that there is a difference between the length of the release of the umbilical cord in babies who are bathed in warm water and babies who are wiped with a wet towel. With a mean difference of 24.72 days when converted into days. The purpose of umbilical cord care is to prevent infectious diseases such as neonatal tetanus in newborns. Neonatorum tetanus is tetanus in newborns with typical clinical signs, after the first 2 days the baby is alive, cries and suckles normally, on the third day or so. There is more stiffness throughout the body which is characterized by difficulty opening the mouth and sucking, followed by convulsions. (WHO, 1989 in Zakariah, 2014). This disease is caused by the entry of spores of tetanus germs into the body through the umbilical cord, either from sterile tools, the use of drugs, powder or leaves sprinkled onto the umbilical cord so that it can cause infection (Indonesian Ministry of Health in Supriyanik, 2011).

The indicator that affects the detachment of the umbilical cord is the care of the umbilical cord by keeping the umbilical cord dry and clean (Gultom, 2004 in Zuniyati.dkk, 2009). The variables that affect the drying and release of the umbilical cord include the baby's birth age, whether it is full term or lack of open or closed umbilical cord care (Rakhmawati, 2007).

According to Choirunisa (2009 in Musariah, 2011) bathing a baby is a way of cleaning the baby's body with water by flushing, immersing oneself in water according to the appropriate sequences. Paisal (2007, in Supriyanik, 2011) said that before the umbilical cord comes off, the baby should not be bathed by dipping it in water. Simply wipe with warm water. The reason is to keep the umbilical cord dry. According to Sodikin (2009 in Hasibuan, 2012), the latest WHO recommendation is to simply clean the base of the umbilical cord using water and soap, then air-dry it so that it is completely dry. - 18 days and even more. The care of the umbilical cord is quite easy and simple, but if it is not done properly by bathing in warm water the amount of water that hits the umbilical cord is more than the care of a baby who is wiped with a wet towel.

This study shows that the drier the baby's body, especially the area around the umbilical cord, the faster the umbilical cord will fall off. The fast detachment of the umbilical cord makes the possibility of infection, especially neonatal tetanus, in infants smaller because the umbilical cord is the entry point for tetanus spores.

If the umbilical cord is wet, there is a greater chance of infection because a wet umbilical cord is a good place for germs and bacteria to breed, including tetanus germ spores. The point is to let the umbilical cord exposed to the air then the umbilical cord will quickly dry and come off. The benefit of good and correct umbilical cord care is that the umbilical cord will be released about 5-7 days after the baby is born without any complications (Saleha, 2009). In addition, according to Dewi (2010), leaving the umbilical cord to dry, not closed and only cleaned every day using clean water is the most effective and cost effective way for umbilical cord care. According to the researcher's assumption, the difference in the length of the umbilical cord detachment occurs because of the difference in the amount of water that reaches the newborn's umbilical cord

\section{Acknowledgement}

The authors would like to thank all those who have helped in completing this research.

\section{Conflict of Interest}

The authors declare that they have no competing interests.

\section{REFERENCES}

Arif, Al. (2004). The Right Way to Take Care of Babies. http://www.anakjenius.comdiung gah on 26 August 2014

Azz, City Ardhillah. (2012). Everything Baby. Yogyakarata : Surya Media Utama. 
Bejo. (2010). Mother's Level of Knowledge About Central Cord Care. http://bejocommunity.com/2010/ 05/kti-level-knowledgeibu-about.

Bidanku.com. How to Bathe a Baby. http://bidanku.com/caramandikan-baby. Research.

Masinon. (2013). Differences in the Effectiveness of Umbilical Cord Treatment at Sarinah Hospital

Cord Treatment with or Pekanbaru in 2013

No Alcohol Against Old Release of the umbilical cord in a new baby Born in the Maternity Home Mother's Love and Mother's Hope Maternity Home Choirunnisa. 2009. Newborn Care. http://digilib.unimus.ac.id/files/disk1/1 22/jtptunimus-gdl-sitimusari-6051-1- babi.pdf

Goddess. (2010). Neonatal Care for Babies and Toddlers. Jakarta : Salemba Medika

Pekanbaru City Health Office. (2014). Report on Infant Mortality Rate in 2012
Dwisuda, (2009). Description of Knowledge of Post Partum Mothers About Umbilical Cord Care at RSIA Sarinah Pekanbaru Pekanbaru in 2009.

Fhatimah. (2012). Relationship of Mother's Knowledge About How to Care for Pangkalan Kerinci Rope, Pelalawan Regency.

Varney H, Kriebs JM, Gegor CL. (2008). Textbook of Midwifery Care. Edition 4. Jakarta: EGC, 2, pp : 894-934.

Azizah RA, Nirmasari C, Andayani , A. (2015). Differences in the time of the release of the umbilical cord wrapped in sterile gauze and open care for infants in the working area of the Ambarawa Public Health Center, Semarang Regency.

Sodikin. (2009). Cord Care. Jakarta: EGC, pp: 67.

Aprillia, Y. (2014). Wharton Jelly "The Magic Jelly" in the Umbilical Cord. http://www.bidankita.com/wharton-jelly-si-jelly-ajaibdalam-tali-central.

Cunningham ,et al (2014). Williams Obstetrics. Edition 23. Jakarta: EGC, 1, pp: 63-436. 